\title{
Role of Estrogen in Thyroid Function and Growth Regulation
}

\author{
Ana Paula Santin ${ }^{1}$ and Tania Weber Furlanetto ${ }^{1,2}$ \\ ${ }^{1}$ Postgraduation Program in Medicine and Medical Sciences, Federal University of Rio Grande do Sul, \\ 90035-003 Porto Alegre, RS, Brazil \\ ${ }^{2}$ Divisão de Medicina Interna, Hospital de Clínicas de Porto Alegre, Universidade Federal do Rio Grande do Sul, \\ Rua Ramiro Barcellos 2350/700, 90035-903 Porto Alegre, RS, Brazil
}

Correspondence should be addressed to Tania Weber Furlanetto, taniafurlanetto@gmail.com

Received 14 January 2011; Accepted 24 February 2011

Academic Editor: Guillermo Juvenal

Copyright ( 2011 A. P. Santin and T. W. Furlanetto. This is an open access article distributed under the Creative Commons Attribution License, which permits unrestricted use, distribution, and reproduction in any medium, provided the original work is properly cited.

\begin{abstract}
Thyroid diseases are more prevalent in women, particularly between puberty and menopause. It is wellknown that estrogen (E) has indirect effects on the thyroid economy. Direct effects of this steroid hormone on thyroid cells have been described more recently; so, the aim of the present paper was to review the evidences of these effects on thyroid function and growth regulation, and its mechanisms. The expression and ratios of the two $\mathrm{E}$ receptors, $\alpha$ and $\beta$, that mediate the genomic effects of $\mathrm{E}$ on normal and abnormal thyroid tissue were also reviewed, as well as nongenomic, distinct molecular pathways. Several evidences support the hypothesis that $\mathrm{E}$ has a direct role in thyroid follicular cells; understanding its influence on the growth and function of the thyroid in normal and abnormal conditions can potentially provide new targets for the treatment of thyroid diseases.
\end{abstract}

\section{Introduction}

Thyroid diseases are more prevalent in women particularly between puberty and menopause [1], and women are more susceptible to the goitrogenic effect of iodine deficiency [2]. Carcinomas of the thyroid are three-times more frequent in women than in men, and the peak rates occur earlier in women [3]. These epidemiological data suggest a role of estrogen in the pathogenesis of thyroid diseases.

Estrogen has a well-known indirect effect on thyroid economy, increasing the thyroxine binding globulin [4], and the need for thyroid hormone in hypothyroid women [5]. Direct effects of estrogen on thyroid cells have been described more recently [6], so the aim of the present paper was to review the evidences of these effects on thyroid function and growth regulation, and its mechanisms.

\section{Estrogen and Its Receptors}

$17-\beta$-estradiol (E2) is a lipophilic hormone with lowmolecular weight that occurs naturally. Cellular signaling of estrogen is mediated classically upon the binding on two soluble intracellular nuclear receptors, estrogen receptor
(ER) alpha, and ER beta [7]. The isoform $\beta$ is smaller than the isoform $\alpha$, and the DNA-binding domains of both subtypes are highly conserved. After binding of E2, ER forms a stable dimer that interacts with specific sequences called estrogen response elements (EREs) to initiate the transcription of target genes. Ligand-bound ERs can also interact with other transcription factors complexes and influence transcription of genes that do not harbor EREs. Third and fourth mechanisms of ERs regulatory actions are, respectively, non-genomic and the ligand independent pathway. A variety of rapid signaling events such as activation of kinases and phosphatases and increases in ion fluxes across membranes has been described. These and other aspects of signaling and targets of ERs have been reviewed recently [7].

Recently, a transmembrane intracellular nonclassical ER mediating rapid cell signaling was described, a $G$ proteincoupled receptor (GPCR), named GPR30 [8].

2.1. Expression of ERs in Human Thyroid Tissue. Classically, the presence of ER is fundamental for a direct action of estrogen in a given cell. ER has been described in both neoplastic and nonneoplastic human thyroid tissues, but the results are discordant. Immunohistochemical assays, 


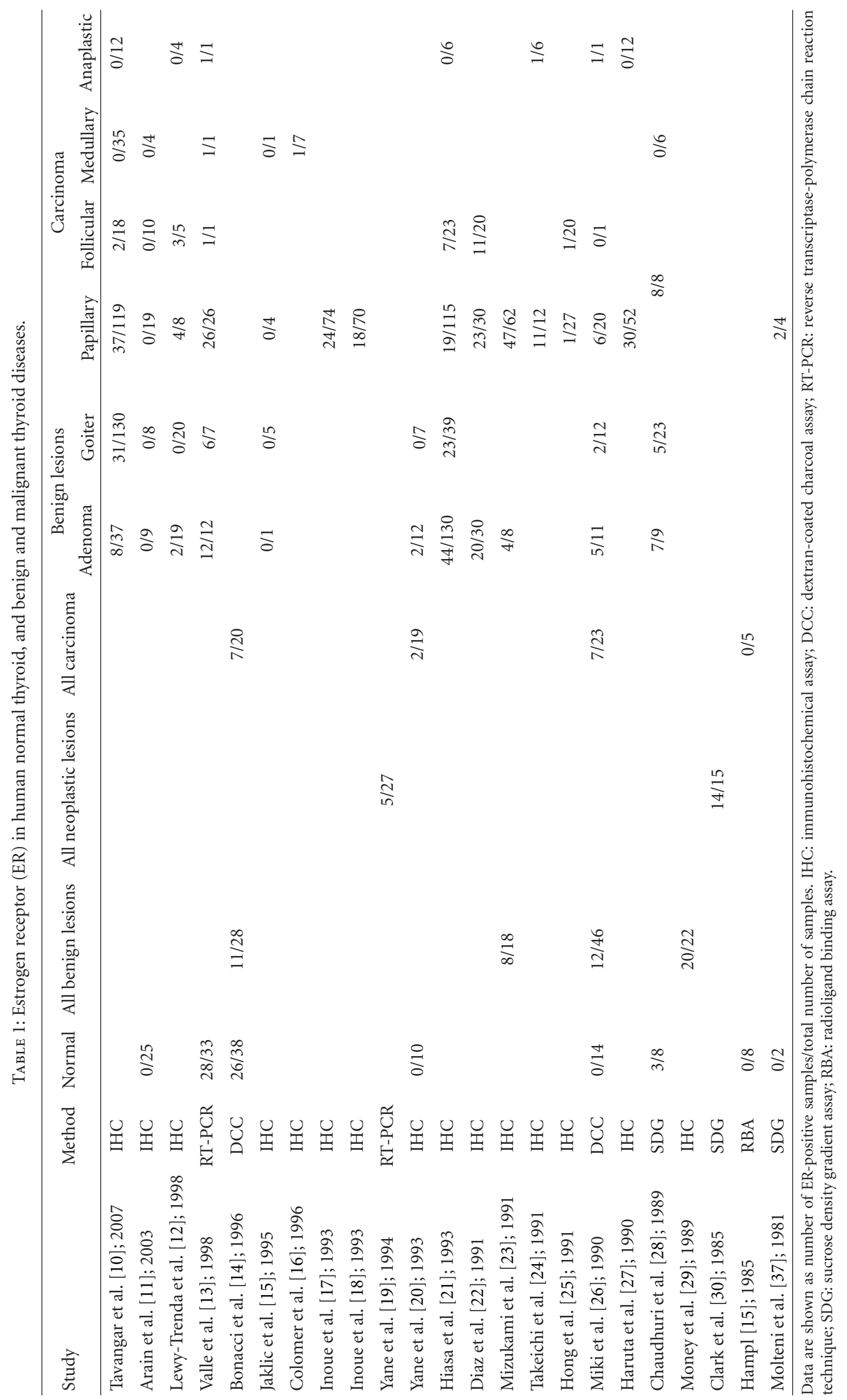


TABLE 2: Estrogen receptors (ER) $\alpha$ and $\beta$ in human normal thyroid, and benign and malignant thyroid diseases, by immunohistochemistry (IHC).

\begin{tabular}{|c|c|c|c|c|c|c|c|c|c|}
\hline \multirow{2}{*}{ Study } & \multirow{2}{*}{ Isoform } & \multirow{2}{*}{ All benign } & \multirow{2}{*}{ All carcinoma } & \multicolumn{2}{|c|}{ Benign lesions } & \multicolumn{4}{|c|}{ Carcinoma } \\
\hline & & & & Adenoma & Goiter & Papillary & Follicular & Medullary & Anaplastic \\
\hline \multirow[t]{2}{*}{ Vaiman et al. [31]; 2010} & $\mathrm{ER} \alpha$ & & & $0 / 34$ & $0 / 150$ & $0 / 90$ & $0 / 6$ & $0 / 4$ & $0 / 5$ \\
\hline & $\mathrm{ER} \beta$ & & & $30 / 34$ & $126 / 150$ & $60 / 90$ & $4 / 6$ & $3 / 4$ & $3 / 5$ \\
\hline Winters et al. [32]; 2010 & $\mathrm{ER} \alpha$ & & & & & $1 / 1$ & & & \\
\hline Vannucchi et al. [33]; 2010 & $\mathrm{ER} \alpha$ & & $12 / 38$ & & & & & & \\
\hline \multirow[t]{2}{*}{ Cho et al. [34]; 2007} & $\mathrm{ER} \alpha$ & & & & & & & $10 / 11$ & \\
\hline & $\mathrm{ER} \beta$ & & & & & & & $8 / 11$ & \\
\hline \multirow[t]{2}{*}{ Bléchet et al. [35]; 2007} & $\mathrm{ER} \alpha$ & & & & & & & $0 / 28$ & \\
\hline & $\mathrm{ER} \beta$ & & & & & & & $26 / 28$ & \\
\hline \multirow[t]{2}{*}{ Ceresini et al. [36]; 2006} & $\mathrm{ER} \alpha$ & & & & $0 / 17$ & $0 / 17$ & & & \\
\hline & $\mathrm{ER} \beta$ & & & & $17 / 17$ & $14 / 17$ & & & \\
\hline
\end{tabular}

Data are shown as number of ER-positive samples/total number of samples.

with monoclonal antibodies, are the most commonly used methods for establishing receptor status. As may be seen in Table 1, some studies have found ER-positivity in normal and abnormal thyroid tissue while others have not detected ER protein in any tissue studied. This discrepancy could be due to methodological issues; the development of monoclonal antibodies against ER with high sensitivity and specificity, and others factors such as tissue fixation, tissue processing, interpretation of immunohistochemistry, and cutoffs for positive results, could have contributed to the sensitivity of the techniques employed [9].

2.2. Expression of ER $\alpha$ and ER $\beta$ in Human Thyroid Tissue. ER expression in human thyroid was first reported in 1981 [37]. $\mathrm{ER} \alpha$ was first described in 1973 [38], and ER $\beta$ was identified in 1996 [39], so only from this moment on it was possible to evaluate the relationship between isoforms of ERs in thyroid tissue. An important role of different patterns of distribution and expression of subtypes ERs in thyroid carcinoma has been proposed: estrogen binding to ER $\alpha$ would promote cell proliferation and growth, and, in contrast, ER $\beta$ would promote apoptotic actions and other suppressive functions in thyroid tumors, as reviewed by Chen et al. [40]. Then, $\mathrm{ER} \alpha: \operatorname{ER} \beta$ ratio could have a role in the pathophysiology of thyroid cancer [40], similar to that postulated for breast cancer [41].

In differentiated thyroid follicular tumors, the expression of $\mathrm{ER} \alpha$ has been associated with well-differentiated tumors and reduced incidence of disease recurrence [54]. ER $\alpha$ protein [55] and ER $\alpha$ mRNA $[19,56]$ are expressed in normal and neoplastic follicular cells of the thyroid. Also, the expression of $\operatorname{ER} \alpha$ and $\operatorname{ER} \beta$ was detected in human medullary thyroid cancer [34] with an increased ratio of $\mathrm{ER} \alpha / \mathrm{ER} \beta$, suggesting a possible role in tumor growth and progression. A few studies evaluated $\mathrm{ER} \alpha$ and $\mathrm{ER} \beta$ expression in normal and abnormal thyroid tissue, as shown in Table 2.

The effects of the agonists of $\operatorname{ER} \alpha$ and $\mathrm{ER} \beta$, respectively, propyl-pyrazole-triol (PPT) and diarylpropionitrile (DPN), in the proliferation of thyroid cancer cell lines has been studied: PPT had a stimulatory effect, while inhibition of proliferation and DNA fragmentation were observed after DPN [45]. In the same study, small interference ribonucleic acid (siRNA) blocking ER $\alpha$ or ER $\beta$ demonstrated that knockdown of the ER $\alpha$ attenuated E2-mediated B-cell lymphoma 2 (Bcl-2) expression, an important antiapoptotic protein, while knockdown of the ER $\beta$ enhanced E2-induced Bcl-2 expression [45].

2.3. Expression of GPR30 in Thyroid Cells Lines. Growing evidence suggests that estrogens are also able to exert nongenomic events mediated by GPR30 [8]. Vivacqua and colleagues analyzed the effects of E2 and the phytoestrogen genistein in human follicular thyroid carcinoma cell lines, WRO and FRO, and ARO, a human anaplastic thyroid carcinoma cell line [46]. Both hormones stimulated in vitro proliferation of these cell lines through the GPR30 and mitogen-activated protein kinase signaling cascade [46]. In other human benign and malignant thyroid tissue, the expression of GPR30 has not been studied.

\section{Response to E2 Stimulation In Vitro}

3.1. Proliferation. Several studies described proliferation of thyroid cells induced by E2, as shown in Table 3. Some of the most commonly used assays are incorporation of bromodeoxyuridine (BrdU) [6], 3-(4,5-dimethylthiazol-2-yl)2,5-diphenyl tetrazolium bromide (MTT) [45, 47, 50, 57], $[(3) \mathrm{H}]$-thymidine incorporation $[48,52,53]$, and trypan blue solution [43]. Cotreatment with ICI182780, fulvestrant, an antagonist of E2 by inhibition and degradation of ER [58], significantly attenuated these proliferative effects.

Based in these studies, E2 increases proliferation of thyroid cells.

3.2. ER-Dependent Effects on Thyroid Differentiation Proteins. Few studies evaluated E2 effect on gene transcription of 
TABLE 3: E2 effects on thyroid protein expression, function, and proliferation in vitro.

\begin{tabular}{|c|c|c|c|c|c|c|c|c|}
\hline Study & Thyroid cells & Presence of $\mathrm{ER} \alpha / \mathrm{ER} \beta$ & $\begin{array}{c}\text { Er } \alpha \\
\text { expression }\end{array}$ & $\begin{array}{c}\operatorname{Er} \beta \\
\text { expression }\end{array}$ & Proliferation & $\begin{array}{c}\text { Nis } \\
\text { expression }\end{array}$ & $\begin{array}{l}\text { Iodide } \\
\text { uptake }\end{array}$ & $\begin{array}{c}\text { TG } \\
\text { mRNA }\end{array}$ \\
\hline \multirow[t]{3}{*}{ Kumar et al. [42]; 2010} & NPA87 & $\mathrm{ER} \alpha+/ \mathrm{ER} \beta+$ & & & $\uparrow$ & & & \\
\hline & KAT5 & $\mathrm{ER} \alpha+/ \mathrm{ER} \beta+$ & & & $\uparrow$ & & & \\
\hline & WRO & $\mathrm{ER} \alpha+/ \mathrm{ER} \beta+$ & & & $\uparrow$ & & & \\
\hline \multirow[t]{2}{*}{ Rajoria et al. [43]; 2010} & BCPAP & $\mathrm{ER} \alpha+/ \mathrm{ER} \beta+$ & & & $\uparrow$ & & & \\
\hline & Nthy-3-1 & $\mathrm{ER} \alpha+/ \mathrm{ER} \beta+$ & & & $\uparrow$ & & & \\
\hline \multirow[t]{2}{*}{ Zeng et al. [44]; 2008} & KAT5 & $\mathrm{ER} \alpha+/ \mathrm{ER} \beta+$ & $\uparrow$ & 0 & $\uparrow$ & & & \\
\hline & FRO & $\mathrm{ER} \alpha+/ \mathrm{ER} \beta+$ & 0 & $\uparrow$ & $\downarrow$ & & & \\
\hline \multirow[t]{3}{*}{ Zeng et al. [45]; 2007} & KAT5 & $\mathrm{ER} \alpha+/ \mathrm{ER} \beta+$ & $\uparrow$ & 0 & $\uparrow$ & & & \\
\hline & FRO & $\mathrm{ER} \alpha+/ \mathrm{ER} \beta+$ & $\uparrow$ & $\uparrow$ & $\uparrow$ & & & \\
\hline & ARO & $\operatorname{ER} \alpha+/ \operatorname{Er} \beta+$ & $\uparrow$ & 0 & $\uparrow$ & & & \\
\hline \multirow[t]{3}{*}{ Vivacqua et al. [46]; 2006} & WRO & $\mathrm{ER} \alpha+/ \mathrm{ER} \beta-$ & & & $\uparrow$ & & & \\
\hline & FRO & $\mathrm{ER} \alpha+/ \mathrm{ER} \beta-$ & & & $\uparrow$ & & & \\
\hline & $\mathrm{ARO}$ & $\mathrm{ER} \alpha-/ \mathrm{ER} \beta-$ & & & $\uparrow$ & & & \\
\hline Lee et al. [47]; 2005 & KAT5 & & & & $\uparrow$ & & & \\
\hline \multirow[t]{2}{*}{ Banu et al. [48]; 2001} & NPA87 & $\mathrm{ER}+$ & & $\uparrow$ & $\uparrow$ & & & \\
\hline & WRO & $\mathrm{ER}+$ & & & $\downarrow$ & & & \\
\hline \multirow[t]{3}{*}{ Manole et al. [6]; 2001} & HTC-TSHr & $\mathrm{ER} \alpha+/ \mathrm{ER} \beta+$ & $\uparrow$ & $\uparrow$ & $\uparrow$ & & & \\
\hline & Goiter & $\mathrm{ER} \alpha+/ \mathrm{ER} \beta+$ & $\uparrow$ & $\uparrow$ & $\uparrow$ & & & \\
\hline & XTC 133 & & & & $\uparrow$ & & & \\
\hline Furlanetto et al. [49]; 2001 & FRTL-5 & & & & $\uparrow$ & & $\downarrow$ & \\
\hline Furlanetto et al. [50]; 1999 & FRTL-5 & $\mathrm{ER} \alpha+$ & & & $\uparrow$ & $\downarrow$ & & \\
\hline \multirow[t]{3}{*}{ Nagy et al. [51]; 1999* } & Mng & & & & $\uparrow$ & & & \\
\hline & $\mathrm{Ca}$ & & & & $\uparrow$ & & & \\
\hline & Ade & & & & $\downarrow$ & & & \\
\hline \multirow[t]{3}{*}{ Del Senno et al. [52]; 1989** } & $\mathrm{N}$ & & & & $\uparrow$ & & & $\uparrow$ \\
\hline & Ade & & & & $\uparrow$ & & & $\uparrow$ \\
\hline & $\mathrm{Ca}$ & & & & 0 & & & 0 \\
\hline Yang et al. [53]; 1988 & $\mathrm{TT}$ & & & & $\uparrow$ & & & \\
\hline
\end{tabular}

Estrogen receptor (ER) +: presence of expression, -: absence of expression; NPA87, KAT5, and BCPAP: human papillary thyroid carcinoma cell lines; WRO and FRO: human follicular thyroid carcinoma cell lines; Nthy-3-1: human normal transformed thyroid cell line; ARO: human anaplastic thyroid carcinoma cell line; HTC-TSHr: human thyroid carcinoma cell line lacking endogenous TSH receptor; XTC-133: thyroid cancer cell line of Hurthle cell origin; FRTL-5: Fischer rat thyroid cell line. Mng: multinodular goiter; Ca: carcinoma; Ade: adenoma; N: normal thyroid; TT: human medullary thyroid carcinoma cell line; $\uparrow$ : increase, $\downarrow$ : decrease, and 0: no effect, after E2 exposure. ${ }^{*}$ : thyroid tissue obtained in surgical resection, under organotypic culture conditions for 48 hours; $* *$ : suspension cultures of thyroid follicles.

differentiation proteins in thyroid cells. In Fischer rat derived thyroid cell line, FRTL-5, E2 treatment decreased the sodium-iodide symporter (NIS) gene expression [50], and the iodide uptake [49]. E2 increased the thyroglobulin gene expression in suspension cultures of human thyroid follicles of adenoma and carcinoma [52]. These data are shown in Table 3. The opposite effects of E2 on the NIS gene expression and iodide uptake, in FRTL-5 cells, and the thyroglobulin gene expression, in suspension culture of thyroid cells, could be due to the different systems studied; it cannot be excluded that estradiol affects these genes by different intracellular pathways. These results, together with the increase in cell growth caused by estrogen, could implicate this hormone in the pathogenesis of goiter and thyroid carcinoma; nevertheless, as just one study evaluated the effect of estrogen on thyroid differentiated proteins in human thyroid tissue, more studies should be done to better understand the role of estrogen in thyroid differentiated protein expression.

3.3. Non-Genomic Effects of E2. Some of the actions of E2 in the proliferation of thyroid cells are mediated by the activation of signal transducing pathways, as shown in 
TABLE 4: Non-genomic estrogen effects on thyroid cells.

\begin{tabular}{|c|c|c|c|c|c|c|c|c|}
\hline Study & Cells & GPR30 & MAPK & PI3k & Cyclin D1 & $c$-fos & BcL-2 & Bax \\
\hline \multirow[t]{3}{*}{ Kumar et al. [42]; 2010} & NPA87 & - & $\uparrow$ & $\uparrow$ & & & & \\
\hline & KAT5 & - & $\uparrow$ & $\uparrow$ & $\uparrow$ & & & \\
\hline & WRO & + & $\uparrow$ & $\uparrow$ & $\uparrow$ & & & \\
\hline \multirow[t]{3}{*}{ Zeng et al. [45]; 2007} & KAT5 & & & & & & $\uparrow$ & $\downarrow$ \\
\hline & FRO & & & & & & $\uparrow$ & $\downarrow$ \\
\hline & WRO & & & & & & $\uparrow$ & $\downarrow$ \\
\hline \multirow[t]{3}{*}{ Vivacqua et al. [46]; 2006} & WRO & + & $\uparrow$ & & $\uparrow$ & $\uparrow$ & & \\
\hline & FRO & + & $\uparrow$ & & $\uparrow$ & $\uparrow$ & & \\
\hline & ARO & + & $\uparrow$ & & $\uparrow$ & $\uparrow$ & & \\
\hline \multirow[t]{3}{*}{ Manole et al. [6]; 2001} & HTC-TSHr & & $\uparrow$ & & $\uparrow$ & & & \\
\hline & Goiter & & $\uparrow$ & & $\uparrow$ & & & \\
\hline & XTC 133 & & $\uparrow$ & & $\uparrow$ & & & \\
\hline
\end{tabular}

NPA87 and KAT5: human papillary thyroid carcinoma cell lines; WRO and FRO: human follicular thyroid carcinoma cell lines; HTC-TSHr: human thyroid carcinoma cell line lacking endogenous TSH receptor; XTC-133: thyroid cancer cell line of Hurthle cell origin; Goiter: primary culture of human thyroid cells isolated from goiter nodules. $(+)$ : presence of expression; $(-)$ absence of expression; ( $\uparrow$ ): increase, $(\downarrow)$ : decrease, and (0): no effects, after E2 exposure.

Table 4. E2 can induce activation of phosphatidylinositol 3-kinase (PI3K) [42] and phosphorylation of extracellular signal-regulated kinase $1 / 2$ (ERK1/2) in follicular thyroid carcinoma cells, mainly due to interaction via membraneassociated ER $[42,45,46]$. PI3K and Erk1/2 signaling may play a critical role in preventing apoptosis and inducing cell cycle progression by induction of key genes expression [59].

Expression of early response genes and regulatory genes of the cell cycle are necessary for proliferation of cells. As E2 has been demonstrated to stimulate the growth of thyroid cells, it is important to study the expression of key cell-cycle genes such as cyclin D1 after stimulation with E2. Cyclin D1 regulates the cell progression cycle facilitating $G_{1}$ to $S$ phase transition and also has an estrogenresponsive regulatory region [60], that is likely different from the canonical EREs. Overexpression of cyclin D1 in thyroid malignancies has been reported [61-65], moreover, its expression has been associated with an aggressive behavior in papillary thyroid microcarcinomas, because over $90 \%$ of the metastasizing microcarcinomas expressed cyclin D1 [66].

E2 significantly increased the expression of cyclin D1 in a human thyroid carcinoma cell line lacking endogenous TSH receptor (HTC-TSHr cells), and in a thyroid cancer cell line of Hurthle cell origin (XTC-133), which was abolished by PD.098059 that blocked G0/G1 to S phases [6]. E2 upregulated cyclins A and D1, as well as the proto-oncogene $c$-fos, in WRO, FRO, and ARO cells [46]. Cyclin D1 was also shown to be upregulated by E2 in KAT5, a papillary thyroid cancer cell line, and WRO cells [42].

Together, these results are very compelling, pointing to an ability of E2 to regulate genes mediating cell cycle progression in thyroid cells, and potentially contributing to the pathogenesis of thyroid cancer or thyroid hyperplasia.

\section{Conclusions}

There are evidences that estrogen may have direct actions in human thyroid cells by ER-dependent mechanisms or not, modulating proliferation, and function. Different patterns of distribution, expression, and ratios of $\mathrm{ER} \alpha$ and $\mathrm{ER} \beta$ may have a role in thyroid cancer cells proliferation, as well as in the outcome of thyroid cancer. Studying estrogen effects on thyroid cells is a potential tool to better understand the pathogenesis of thyroid diseases, and to develop targets to its treatment. Further studies on the influence of E2 on the growth and function of the thyroid are needed, preferably in primary culture of normal and abnormal human thyroid cells.

\section{Conflict of Interests}

The authors declare that there is no conflict of interests.

\section{References}

[1] M. P. J. Vanderpump, W. M. G. Tunbridge, J. M. French et al., "The incidence of thyroid disorders in the community: a twenty-year follow-up of the Whickham Survey," Clinical Endocrinology, vol. 43, no. 1, pp. 55-68, 1995.

[2] P. Laurberg, K. M. Pedersen, A. Hreidarsson, N. Sigfusson, E. Iversen, and P. R. Knudsen, "Iodine intake and the pattern of thyroid disorders: a comparative epidemiological study of thyroid abnormalities in the elderly in iceland and in Jutland, Denmark," Journal of Clinical Endocrinology and Metabolism, vol. 83, no. 3, pp. 765-769, 1998.

[3] L. Enewold, K. Zhu, E. Ron et al., "Rising thyroid cancer incidence in the United States by demographic and tumor characteristics, 1980-2005," Cancer Epidemiology Biomarkers and Prevention, vol. 18, no. 3, pp. 784-791, 2009.

[4] Z. Ben-Rafael, J. F. Struass, B. Arendash-Durand, L. Mastroianni, and G. L. Flickinger, "Changes in thyroid function tests and sex hormone binding globulin associated with 
treatment by gonadotropin," Fertility and Sterility, vol. 48, no. 2, pp. 318-320, 1987.

[5] B. M. Arafah, "Increased need for thyroxine in women with hypothyroidism during estrogen therapy," New England Journal of Medicine, vol. 344, no. 23, pp. 1743-1749, 2001.

[6] D. Manole, B. Schildknecht, B. Gosnell, E. Adams, and M. Derwahl, "Estrogen promotes growth of human thyroid tumor cells by different molecular mechanisms," Journal of Clinical Endocrinology and Metabolism, vol. 86, no. 3, pp. 1072-1077, 2001.

[7] N. Heldring, A. Pike, S. Andersson et al., "Estrogen receptors: how do they signal and what are their targets," Physiological Reviews, vol. 87, no. 3, pp. 905-931, 2007.

[8] C. M. Revankar, D. F. Cimino, L. A. Sklar, J. B. Arterburn, and E. R. Prossnitz, "A transmembrane intracellular estrogen receptor mediates rapid cell signaling," Science, vol. 307, no. 5715, pp. 1625-1630, 2005.

[9] A. M. Gown, "Current issues in ER and HER2 testing by IHC in breast cancer," Modern Pathology, vol. 21, no. 2, pp. S8-S15, 2008.

[10] S. M. Tavangar, M. Monajemzadeh, B. Larijani, and V. Haghpanah, "Immunohistochemical study of oestrogen receptors in 351 human thyroid glands," Singapore Medical Journal, vol. 48, no. 8, pp. 744-747, 2007.

[11] S. A. Arain, M. H. Shah, S. A. Meo, and Q. Jamal, "Estrogen receptors in human thyroid gland. An immunohistochemical study," Saudi Medical Journal, vol. 24, no. 2, pp. 174-178, 2003.

[12] I. Lewy-Trenda, "Estrogen receptors in the malignant and benign neoplasms of the thyroid," Polski Merkuriusz Lekarski, vol. 5, no. 26, pp. 80-83, 1998.

[13] L. D. Valle, A. Ramina, S. Vianello, A. Fassina, P. Belvedere, and L. Colombo, "Potential for estrogen synthesis and action in human normal and neoplastic thyroid tissues," Journal of Clinical Endocrinology and Metabolism, vol. 83, no. 10, pp. 3702-3709, 1998.

[14] R. Bonacci, A. Pinchera, P. Fierabracci, A. Gigliotti, L. Grasso, and C. Giani, "Relevance of estrogen and progesterone receptors enzyme immunoassay in malignant, benign and surrounding normal thyroid tissue," Journal of Endocrinological Investigation, vol. 19, no. 3, pp. 159-164, 1996.

[15] B. R. Jaklic, J. Rushin, and B. C. Ghosh, "Estrogen and progesterone receptors in thyroid lesions," Annals of Surgical Oncology, vol. 2, no. 5, pp. 429-434, 1995.

[16] A. Colomer, J. V. Martínez-Mas, X. Matias-Guiu et al., "Sex-steroid hormone receptors in human medullary thyroid carcinoma," Modern Pathology, vol. 9, no. 1, pp. 68-72, 1996.

[17] H. Inoue, K. Oshimo, H. Miki et al., "Immunohistochemical study of estrogen receptor and estradiol on papillary thyroid carcinoma in young patients," Journal of Surgical Oncology, vol. 53, no. 4, pp. 226-230, 1993.

[18] H. Inoue, K. Oshimo, H. Miki, M. Kawano, and Y. Monden, "Immunohistochemical study of estrogen receptors and the responsiveness to estrogen in papillary thyroid carcinoma," Cancer, vol. 72, no. 4, pp. 1364-1368, 1993.

[19] K. Yane, Y. Kitahori, N. Konishi et al., "Expression of the estrogen receptor in human thyroid neoplasms," Cancer Letters, vol. 84, no. 1, pp. 59-66, 1994.

[20] K. Yane, O. Tanaka, H. Miyahara, T. Matsunaga, Y. Kitahori, and Y. Hiasa, "Immunohistochemical study of epidermal growth factor receptor and estrogen receptor in human thyroid tumors," Journal of Otolaryngology of Japan, vol. 96, no. 5, pp. 787-790, 1993.

[21] Y. Hiasa, H. Nishioka, Y. Kitahori et al., "Immunohistochemical analysis of estrogen receptors in 313 paraffin section cases of human thyroid tissue," Oncology, vol. 50, no. 2, pp. 132-136, 1993.

[22] N. M. Diaz, G. Mazoujian, and M. R. Wick, "Estrogenreceptor protein in thyroid neoplasms. An immunohistochemical analysis of papillary carcinoma, follicular carcinoma, and follicular adenoma," Archives of Pathology and Laboratory Medicine, vol. 115, no. 12, pp. 1203-1207, 1991.

[23] Y. Mizukami, T. Michigishi, A. Nonomura, T. Hashimoto, M. Noguchi, and F. Matsubara, "Estrogen and estrogen receptors in thyroid carcinomas," Journal of Surgical Oncology, vol. 47, no. 3, pp. 165-169, 1991.

[24] N. Takeichi, H. Ito, R. Haruta, T. Matsuyama, K. Dohi, and E. Tahara, "Relation between estrogen receptor and malignancy of thyroid cancer," Japanese Journal of Cancer Research, vol. 82, no. 1, pp. 19-22, 1991.

[25] G. S. Hong, I. T. Y. Sng, and K. C. Soo, "Oestrogen receptors in well differentiated thyroid cancers," Annals of the Academy of Medicine Singapore, vol. 20, no. 6, pp. 767-769, 1991.

[26] H. Miki, K. Oshimo, H. Inoue, T. Morimoto, and Y. Monden, "Sex hormone receptors in human thyroid tissues," Cancer, vol. 66, no. 8, pp. 1759-1762, 1990.

[27] R. Haruta, H. Ito, N. Takeichi, T. Matsuyama, K. Dohi, and E. Tahara, "An immunohistochemical study of estrogen receptors in thyroid carcinoma," Gan No Rinsho, vol. 36, no. 4, pp. 465468, 1990.

[28] P. K. Chaudhuri and R. Prinz, "Estrogen receptor in normal and neoplastic human thryoid tissue," American Journal of Otolaryngology, vol. 10, no. 5, pp. 322-326, 1989.

[29] S. R. Money, W. Muss, W. L. Thelmo et al., "Immunocytochemical localization of estrogen and progesterone receptors in human thyroid," Surgery, vol. 106, no. 6, pp. 975-979, 1989.

[30] O. H. Clark, P. L. Gerend, and M. Davis, "Estrogen and thyroid-stimulating hormone (TSH) receptors in neoplastic and nonneoplastic human thyroid disease," Journal of Surgical Research, vol. 38, no. 2, pp. 89-96, 1985.

[31] M. Vaiman, Y. Olevson, L. Habler, A. Kessler, S. Zehavi, and J. Sandbank, "Diagnostic value of estrogen receptors in thyroid lesions," Medical Science Monitor, vol. 16, no. 7, pp. 203-207, 2010.

[32] A. Winters, P. Friedlander, B. M. Jaffe, M. A. Khalek, K. Moroz, and E. Kandil, "A postmenopausal woman with gross cystic disease fluid protein-15 and estrogen receptor-positive recurrence of papillary thyroid cancer," Thyroid, vol. 20, no. 12, pp. 1413-1417, 2010.

[33] G. Vannucchi, M. Perrino, S. Rossi et al., "Clinical and molecular features of differentiated thyroid cancer diagnosed during pregnancy," European Journal of Endocrinology, vol. 162, no. 1, pp. 145-151, 2010.

[34] M. A. Cho, M. K. Lee, K. H. Nam et al., "Expression and role of estrogen receptor $\alpha$ and $\beta$ in medullary thyroid carcinoma: different roles in cancer growth and apoptosis," Journal of Endocrinology, vol. 195, no. 2, pp. 255-263, 2007.

[35] C. Bléchet, P. Lecomte, L. De Calan, P. Beutter, and S. Guyétant, "Expression of sex steroid hormone receptors in C cell hyperplasia and medullary thyroid carcinoma," Virchows Archiv, vol. 450, no. 4, pp. 433-439, 2007.

[36] G. Ceresini, S. Morganti, V. Graiani et al., "Estrogen receptor (ER)- $\beta$, but not ER- $\alpha$, is present in thyroid vessels: immunohistochemical evaluations in multinodular goiter and papillary thyroid carcinoma," Thyroid, vol. 16, no. 12, pp. 1215-1220, 2006.

[37] A. Molteni, R. L. Warpeha, L. Brizio-Molteni, and E. M. Fors, "Estradiol receptor-binding protein in head and neck 
neoplastic and normal tissue," Archives of Surgery, vol. 116, no. 2, pp. 207-210, 1981.

[38] E. V. Jensen and E. R. DeSombre, "Estrogen receptor interaction," Science, vol. 182, no. 4108, pp. 126-134, 1973.

[39] S. Mosselman, J. Polman, and R. Dijkema, "ER $\beta$ : identification and characterization of a novel human estrogen receptor," FEBS Letters, vol. 392, no. 1, pp. 49-53, 1996.

[40] G. G. Chen, A. C. Vlantis, Q. Zeng, and C. A. Van Hasselt, "Regulation of cell growth by estrogen signaling and potential targets in thyroid cancer," Current Cancer Drug Targets, vol. 8, no. 5, pp. 367-377, 2008.

[41] A. M. Sotoca, H. Van den Berg, J. Vervoort et al., "Influence of cellular $\mathrm{ER} \alpha / \mathrm{ER} \beta$ ratio on the $\mathrm{ER} \alpha$-agonist induced proliferation of human T47D breast cancer cells," Toxicological Sciences, vol. 105, no. 2, pp. 303-311, 2008.

[42] A. Kumar, C. M. Klinge, and R. E. Goldstein, "Estradiolinduced proliferation of papillary and follicular thyroid cancer cells is mediated by estrogen receptors $\alpha$ and $\beta$," International Journal of Oncology, vol. 36, no. 5, pp. 1067-1080, 2010.

[43] S. Rajoria, R. Suriano, A. Shanmugam et al., "Metastatic phenotype is regulated by estrogen in thyroid cells," Thyroid, vol. 20, no. 1, pp. 33-41, 2010.

[44] Q. Zeng, G. G. Chen, A. C. Vlantis, G. M. Tse, and C. A. Van Hasselt, "The contributions of oestrogen receptor isoforms to the development of papillary and anaplastic thyroid carcinomas," Journal of Pathology, vol. 214, no. 4, pp. 425-433, 2008.

[45] Q. Zeng, G. G. Chen, A. C. Vlantis, and C. A. Van Hasselt, "Oestrogen mediates the growth of human thyroid carcinoma cells via an oestrogen receptor-ERK pathway," Cell Proliferation, vol. 40, no. 6, pp. 921-935, 2007.

[46] A. Vivacqua, D. Bonofiglio, L. Albanito et al., " $17 \beta$-Estradiol, genistein, and 4-hydroxytamoxifen induce the proliferation of thyroid cancer cells through the $\mathrm{G}$ protein-coupled receptor GPR30," Molecular Pharmacology, vol. 70, no. 4, pp. 14141423, 2006.

[47] M. L. Lee, G. G. Chen, A. C. Vlantis, G. M. K. Tse, B. C. H. Leung, and C. A. Van Hasselt, "Induction of thyroid papillary carcinoma cell proliferation by estrogen is associated with an altered expression of Bcl-xL," Cancer Journal, vol. 11, no. 2, pp. 113-121, 2005.

[48] K. S. Banu, P. Govindarajulu, and M. M. Aruldhas, "Testosterone and estradiol have specific differential modulatory effect on the proliferation of human thyroid papillary and follicular carcinoma cell lines independent of TSH action," Endocrine Pathology, vol. 12, no. 3, pp. 315-327, 2001.

[49] T. W. Furlanetto, R. B. Nunes, A. M. I. Sopelsa, and R. M. B. Maciel, "Estradiol decreases iodide uptake by rat thyroid follicular FRTL-5 cells," Brazilian Journal of Medical and Biological Research, vol. 34, no. 2, pp. 259-263, 2001.

[50] T. W. Furlanetto, L. Q. Nguyen, and J. L. Jameson, "Estradiol increases proliferation and down-regulates the sodium/iodide symporter gene in FRTL-5 cells," Endocrinology, vol. 140, no. 12, pp. 5705-5711, 1999.

[51] N. Nagy, I. Camby, C. Decaestecker et al., "The influence of Ltriiodothyronine, L-thyroxine, estradiol-17 $\beta$, the luteinizinghormone-releasing hormone, the epidermal growth factor and gastrin on cell proliferation in organ cultures of 35 benign and 13 malignant human thyroid tumors," Journal of Cancer Research and Clinical Oncology, vol. 125, no. 6, pp. 361-368, 1999.

[52] L. Del Senno, E. Degli Uberti, S. Hanau, R. Piva, R. Rossi, and G. Trasforini, "In vitro effects of estrogen on tgb and c-myc gene expression in normal and neoplastic human thyroids," Molecular and Cellular Endocrinology, vol. 63, no. 1-2, pp. 6774, 1989.

[53] K. Yang, C. E. Pearson, and N. A. Samaan, "Estrogen receptor and hormone responsiveness of medullary thyroid carcinoma cells in continuous culture," Cancer Research, vol. 48, no. 10, pp. 2760-2763, 1988.

[54] D. O. Kavanagh, M. McIlroy, E. Myers et al., "The role of oestrogen receptor $\alpha$ in human thyroid cancer: contributions from coregulatory proteins and the tyrosine kinase receptor HER2," Endocrine-Related Cancer, vol. 17, no. 1, pp. 255-264, 2010.

[55] C. Lee et al., "Estrogen receptors and glucocorticoid receptors in human well-differentiated thyroid cancer," International Journal of Molecular Medicine, vol. 2, no. 2, pp. 229-233, 1998.

[56] C. Egawa, Y. Miyoshi, K. Iwao, E. Shiba, and S. Noguchi, "Quantitative analysis of estrogen receptor- $\alpha$ and $-\beta$ messenger RNA expression in normal and malignant thyroid tissues by real-time polymerase chain reaction," Oncology, vol. 61, no. 4, pp. 293-298, 2001.

[57] T. Hoelting, S. Tezelman, A. E. Siperstein, Q. Y. Duh, and O. H. Clark, "Biphasic effects of thyrotropin on invasion and growth of papillary and follicular thyroid cancer in vitro," Thyroid, vol. 5, no. 1, pp. 35-40, 1995.

[58] V. Marsaud, A. Gougelet, S. Maillard, and J.-M. Renoir, "Various phosphorylation pathways, depending on agonist and antagonist binding to endogenous estrogen receptor $\alpha$ $(\mathrm{ER} \alpha)$, differentially affect $\mathrm{ER} \alpha$ extractability, proteasomemediated stability, and transcriptional activity in human breast cancer cells," Molecular Endocrinology, vol. 17, no. 10, pp. 2013-2027, 2003.

[59] M. Saji and M. D. Ringel, "The PI3K-Akt-mTOR pathway in initiation and progression of thyroid tumors," Molecular and Cellular Endocrinology, vol. 321, no. 1, pp. 20-28, 2010.

[60] L. Altucci, R. Addeo, L. Cicatiello et al., " $17 \beta$-estradiol induces cyclin D gene transcription, p36(D)-p34(cdk4) complex activation and $\mathrm{p} 105(\mathrm{Rb})$ phosphorylation during mitogenic stimulation of G-arrested human breast cancer cells," Oncogene, vol. 12, no. 11, pp. 2315-2324, 1996.

[61] S. Sporny, D. Slowinska-Klencka, and M. Ratynska, "Cyclin D1 expression in primary thyroid carcinomas," Neuroendocrinology Letters, vol. 26, no. 6, pp. 815-818, 2005.

[62] Y. Shi, M. Zou, E. Varkondi, A. Nagy, L. Kozma, and N. R. Farid, "Cyclin D1 in thyroid carcinomas," Thyroid, vol. 11, no. 7, pp. 709-710, 2001.

[63] F. Basolo, M. A. Caligo, A. Pinchera et al., "Cyclin D1 overexpression in thyroid carcinomas: relation with clinicopathological parameters, retinoblastoma gene product, and ki67 labeling index," Thyroid, vol. 10, no. 9, pp. 741-746, 2000.

[64] D. Lazzereschi, L. Sambuco, C. Carnuvale Scalzo et al., "Cyclin D1 and cyclin E expression in malignant thyroid cells and in human thyroid carcinomas," International Journal of Cancer, vol. 76, no. 6, pp. 806-811, 1998.

[65] S. Wang, R. V. Lloyd, M. J. Hutzler, M. S. Safran, N. A. Patwardhan, and A. Khan, "The role of cell cycle regulatory protein, cyclin D1, in the progression of thyroid cancer," Modern Pathology, vol. 13, no. 8, pp. 882-887, 2000.

[66] M. L. C. Khoo, S. Ezzat, J. L. Freeman, and S. L. Asa, "Cyclin D1 protein expression predicts metastatic behavior in thyroid papillary microcarcinomas but is not associated with gene amplification," Journal of Clinical Endocrinology and Metabolism, vol. 87, no. 4, pp. 1810-1813, 2002. 


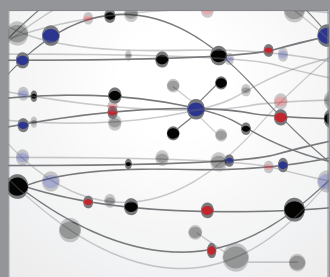

The Scientific World Journal
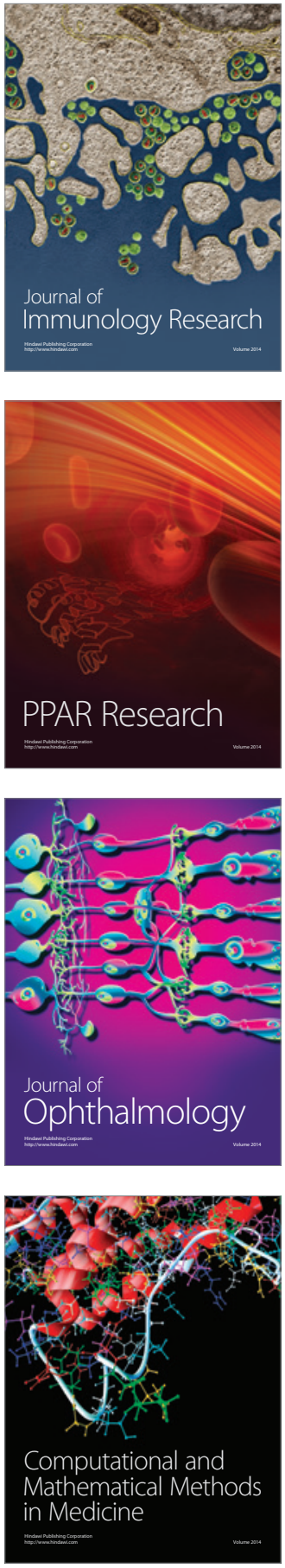

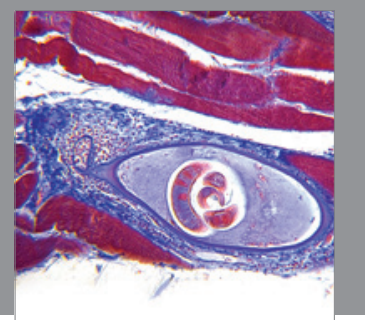

Gastroenterology

Research and Practice
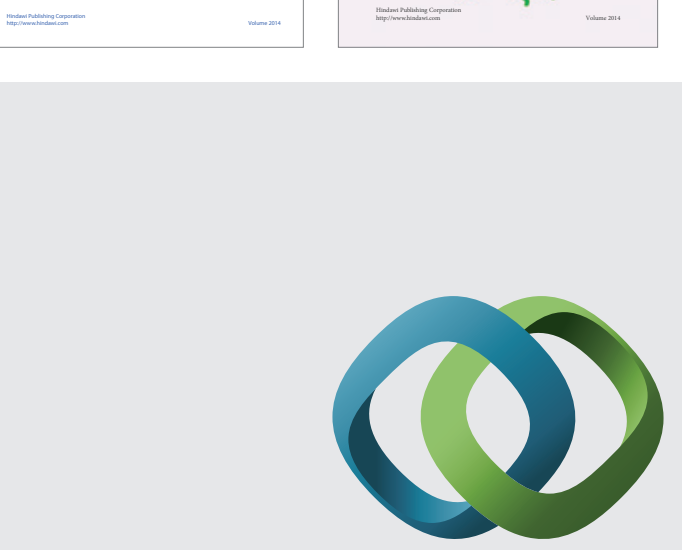

\section{Hindawi}

Submit your manuscripts at

http://www.hindawi.com
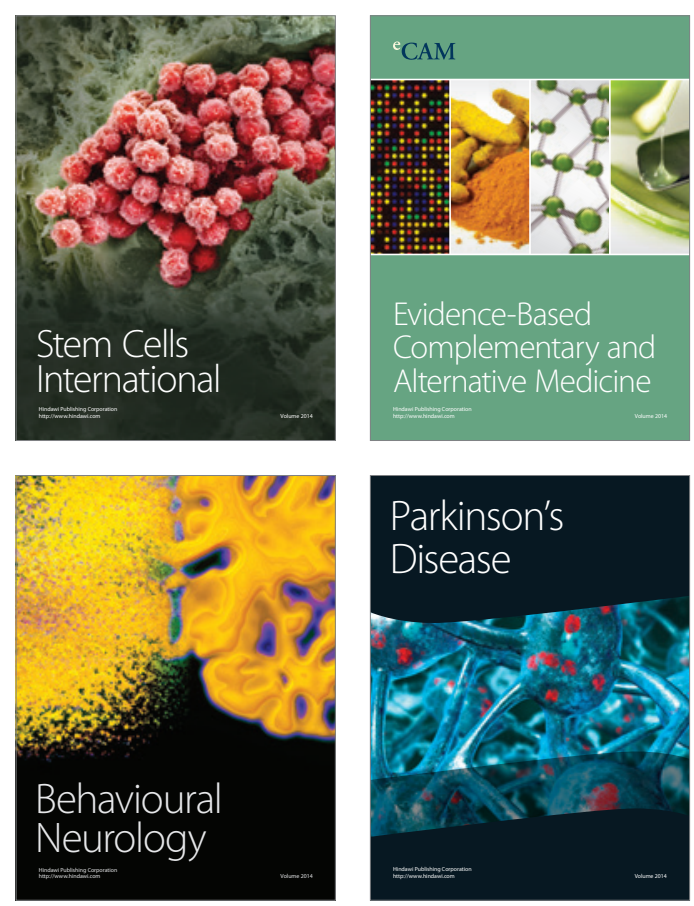

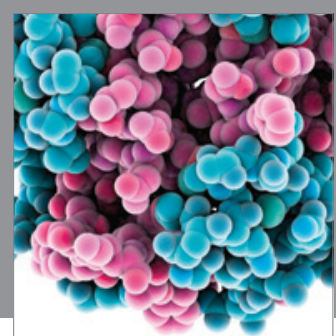

Journal of
Diabetes Research

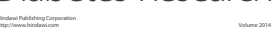

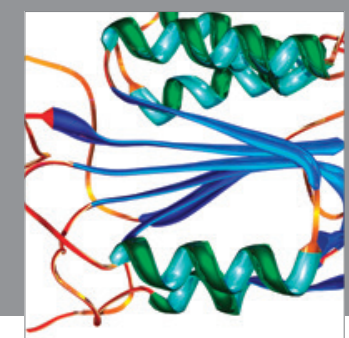

Disease Markers
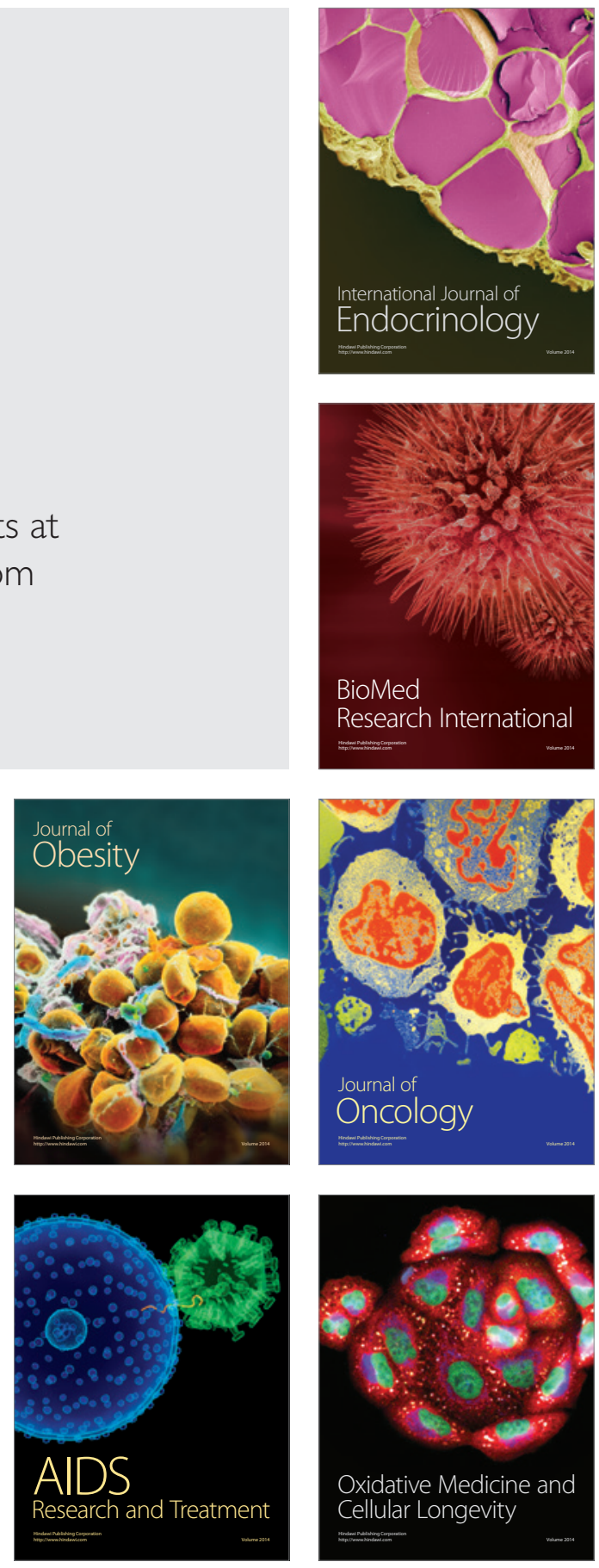